\title{
Exploring Linguistic Identity in Young Multilingual Learners
}

Roswita Dressler

This article explores the linguistic identity of young multilingual learners through the use of a Language Portrait Silhouette. Examples from a research study of children aged 6-8 years in a German bilingual program in Canada provide teachers with an understanding that linguistic identity comprises expertise, affiliation, and inheritance. This article also provides additional concrete examples of how teachers can openly reference linguistic identity with students and help children to see stronger connections between home and school learning. The validation and understanding of linguistic identity is beneficial to young children's emotional, social, and educational development.

Cet article examine l'identité linguistique de jeunes apprenants plurilingues par l'emploi d'un portrait silhouette langagière (Language Portrait Silhouette). Quelques exemples d'une recherche portant sur des élèves âgés de 6 à 8 ans dans un programme allemand bilingue au Canada démontrent aux enseignants que l'identité linguistique comprend les aspects l'expertise, l'affiliation et l'héritage. Cet article offre également des exemples concrets sur diverses façons de parler ouvertement d'identité linguistique avec les élèves et de les aider à établir des liens plus solides entre ce qu'ils apprennent à l'école et à la maison. Le fait de valider et de comprendre l'identité linguistique favorise le développement affectif, social et éducationnel des jeunes enfants.

Canadian elementary school classrooms are filled with young children of all shapes and sizes whose stories are even more varied than their appearances. Listening to them on the playground or when they are picked up by parents or caregivers, one may encounter those children speaking more languages than they speak in the classroom. These languages are so much a part of who they are, but teachers may not realize their presence. Teachers can openly acknowledge the linguistic identity of students by encouraging students to identify the languages they speak and by initiating a discussion of the usefulness of knowing more than one language. These actions acknowledge the value of the diverse cultural and linguistic resources the children bring to the classroom. Reference to these linguistic resources during classroom learning draws upon previous knowledge and can help children to see stronger connections between home and school learning. 
Young children, as they enter school, are just beginning to understand themselves as separate from their parents (Eccles, 1999). Part of that separate identity is their linguistic identity as speakers of one or more languages (Block, 2014). This linguistic identity can be expressed in terms of expertise (i.e., linguistic competence), affiliation (formal or informal connections), or inheritance (familial connections) (Leung, Harris, \& Rampton, 1997). In a multilingual classroom, teachers have the opportunity to explore what linguistic identity means to these children (Cummins \& Early, 2011). This exploration begins a dialogue that enhances relationships between teachers and students and among students.

German bilingual programs in Canada are situated in schools with multilingual learners and offer a setting for the exploration of linguistic identity. The students enrolled in the German bilingual program in this study had German and English as the languages of instruction. In some homes, families spoke only English, German, or another language. In other homes, families spoke English and German, English and another language, or German and another language. A questionnaire completed by parents ( $48.6 \%$ return rate) revealed that a home language other than English was used in $76 \%$ of the households. In some cases (8\%), these home languages were used instead of English, but for the majority (68\%) of multilingual households, both the home language(s) and English were used. In exploring linguistic identity, the voices of these young multilingual children were elicited through the use of the Language Portrait Silhouette (LPS). The use of the LPS was extended in this study by bringing it together with linguistic identity as expressed through expertise, affiliation, and inheritance.

\section{The Language Portrait Silhouette Task}

An age-appropriate task that can be used by children from a variety of language backgrounds is the Language Portrait Silhouette, where students colour in their languages on a drawn silhouette of a body (Krumm \& Jenkins, 2001). The symbolic expression of linguistic identity through the LPS task (see Figure 1) is combined with the children's own verbal descriptions of why they chose the colours, shapes, and symbols they did. A multimodal analysis provided insight into the linguistic identities of the students in this study.

Researchers are interested in exploring children's expression of multilingual competence in settings where the language of classroom instruction may not reflect the linguistic repertoire of the students. Several groups of European researchers have used the LPS to investigate language awareness and language identity (Arnesen, Allan, Simonsen, \& Council of Europe, 2010; Gogolin \& Neumann, 1991; Krumm \& Jenkins, 2001; Portnaia, 2014). Busch $(2010,2012)$ used the LPS with both children and adults, asking them to provide a written text to go along with their coloured drawing which she then analyzed using a poststructuralist approach. Martin (2012) had Grade 4 bi- 
lingual education students in Germany complete a questionnaire along with their LPS, which provided understanding of how responses differ according to the support those languages have in the classroom. Lundell (2010) used the LPS to analyze how English was visually portrayed in the linguistic identity of children in Finland. The children orally explained their choice of colour and placement during a group sharing activity. My approach adapted the use of the LPS to younger children by choosing an oral over written explanation (similar to Lundell, 2010) and choosing an individual expression over a group activity (similar to Busch 2010, 2012; Martin, 2012). The multimodal analysis was supported by the use of videotape so that each child could speak to the LPS immediately after he or she had completed the task. In that way, all of the children could remember why they chose the colours they did and had ample time to share their thoughts.

As a part of a larger study, I brought the LPS task to the research site for a whole focus class of Grade 1 and 2 students to complete. I chose this classroom because the two teachers who team-taught in it had opened their classroom to me for my larger study and wanted all of the children to complete the LPS. In addition, the class contained 11 children who spoke another language at home. Parents of 13 children had granted permission for their participation

\section{These are my languages/Das sind meine Sprachen}

Color in the figure with your languages. For each language, choose a different color. Explain why you chose the colors you did and why you placed them where you did.

Male deine Sprachen in die Figur und nimm für jede Sprache eine andere Farbe. Erläutere deine Zuordnung.

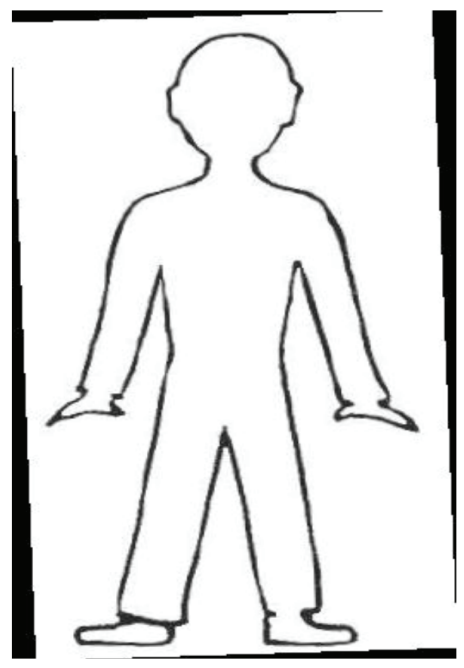

Figure 1: Language Portrait Silhouette ${ }^{1}$ 
in videotaped classroom observations. The children were given the instructions to "colour in your languages where they are in your body" and create a key along the side to explain which colour was used for each language.

One by one, each of the focus children explained their LPS to me while a video camera captured our words and gestures. The multimodality of the task afforded the children multiple forms of representation (oral, visual, textual) and resulted in metaphoric semiotic representations (e.g., colour, shapes, flags) (Kress, 2010). Videotaping the children required them to transform their manual and visual mode of drawing into the verbal mode of language as speech augmented by gesture (primarily pointing) (Kress \& van Leeuwen, 2006). In my analysis, I examined how these multiple modes and representations were used by the children to make meaning for the expression of their linguistic identity as expertise, affiliation, and/or inheritance.

\section{Different Children, Different Stories}

Each child was individually asked, "Tell me about your picture." Each child's drawings have been recreated here in Microsoft Paint to protect their identity, and pseudonyms are used to refer to the children. For many of the children, these explanations referenced aspects of emerging bilingual identity: expertise, affiliation, and inheritance. For the purpose of this article, I will focus on the LPSs of 7 children: Sean and Stryker (age 6); Fiona, Reja, Earl, and Yousef (age 7); and Zane (age 8). These children represent the linguistic profiles of the focus classroom: Fiona, Earl, and Zane were monolinguals learning German through school and Sean, Stryker, Reja, and Yousef were multilinguals with two or more languages at home.

\section{Expertise}

Expertise is the aspect of linguistic identity built upon how much of the language a child knows (Block, 2014). In referencing expertise, children typically spoke of their oral skills in the language. They all embrace plurilingualism to varying degrees (Moore, 2010) and, in one case, isolated words in various languages were used to demonstrate that expertise through translanguaging (Garcia, 2009). In addition, they used the LPS to position their languages concretely in their silhouette, drawing upon "metaphoric arrangements" in their environment: the body and flags (Kress, 1997, p. 97). Through looking at their words and their drawings, insights into their perceptions of their linguistic expertise emerge.

Most children were cautious in quantifying their expertise. Fiona said, "I speak a little bit of Spanish and a little bit of French," and Reja said, "I can speak both of them," in reference to German and English. Yousef, when asked if he spoke German to his grandmother, wrinkled his nose and answered "not really." Some children also compared their knowledge of one language with that of other languages in their repertoire: "I know [English] the most" 
(Fiona). In contrast to Fiona and Reja, Zane expressed a belief that knowing any number of words in a language entitled him to consider himself a speaker of that language. When asked to explain how much he spoke of each language represented in his LPS (see Figure 2), he responded: "How much can I speak of the language? Spanish, I can speak about five words; French, about two words; Portuguese, one word; Russian, one." When asked what he could say in Portuguese and Russian, he offered "grenado ... grenade" and "do svidaniya [good bye]." He also demonstrated his expertise in German through playful translanguaging, labelling German as "Deutsch" in the key for this LPS. For these children, "knowing" a language involved speaking it, even if they only knew a few words, thereby embracing an emerging plurilingualism.

Many children took advantage of the figure on the LPS to align their languages according to body parts and through the use of flags (similar to the children in the Lundell, 2010, study). The head or brain often represented "knowing." Earl spoke of German being located in his head: "I first remembered the words when I went to Germany so I still have the words that I have in my head." In contrast, hands, arms, and feet, being farther away from the head and used for gesturing, often represented "not knowing." The children explained that they had to resort to gestures with hands and feet when they couldn't express themselves with words. Earl related a story about his memories of a trip to a country, the name of which he had forgotten. Pointing at the unknown flag in the picture and then lightly flapping his arms (see Figure 3), he said, "I'm not really good at speaking it, but I am good of [sic] acting it with my arms." Sean pointed to the head in his picture then tapped his forehead once, saying "and I think in German." Kress (1997) points out the multimodality of children's expressions of early literacy. In this analysis, the multimodality of the children's answers in locating their languages within a

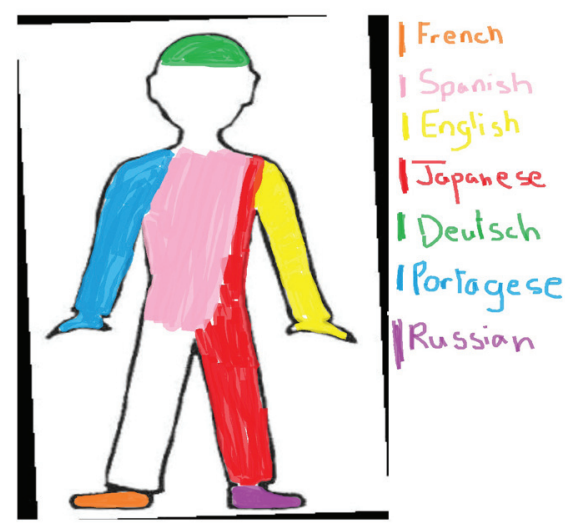

Figure 2: Zane's Language Portrait Silhouette 
body outline or through the use of flags, and accompanying these answers with gesture, facilitated the children's expression of their linguistic expertise.

Even at a young age, children have a concept of what it means to "know" a language. Interestingly, they express "lack of knowing" rather matter-offactly. Although adults are often reluctant to claim competence with a language if their expertise is minimal or does not involve reading and writing (Dressler, 2010), these children did not share this reluctance. Their linguistic identity drew strongly upon oral competence as a measure of linguistic expertise.

\section{Affiliation}

Affiliation is often expressed as identification or attachment to a language (Block, 2014). For the children, this identification was often represented through the use of the flag of a country where the language is spoken (Lundell, 2010). They expressed attachment in terms of "liking" language, often using placement in the body outline to indicate degree of "liking." Both expressions of affiliation were found in the LPS descriptions of the children in this classroom.

Similar to Earl, Reja used flags on her LPS and matched the colour of the flags to the colours on the LPS (Figure 4). Like the children in the Lundell (2010) study who often chose blue, the colour on the Finnish flag, to represent Finnish, this choice was not verbalized by Earl and Reja. Reja represented German with the German flag and English with the Canadian flag, but she also used the names of the countries to signify the languages represented symmetrically in her body. "One half is Germany and one half is Canada." Her strong attachment to the countries where the languages are spoken make up an aspect of her linguistic identity and, in expressing this affiliation, she

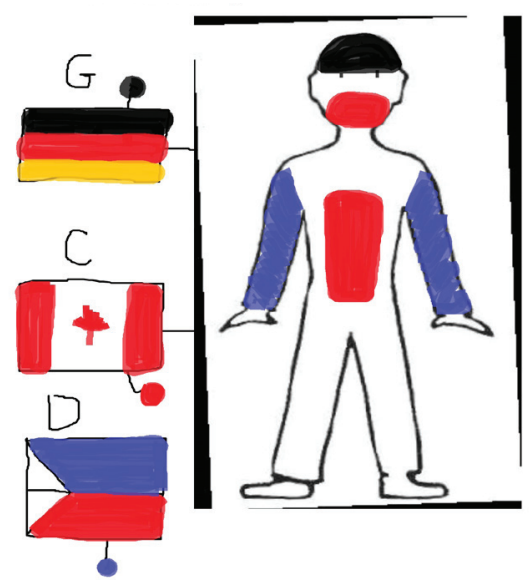

Figure 3: Earl's Language Portrait Silhouette 
draws upon metaphoric arrangements from the classroom and her home: the flags of Germany and Canada.

Students used the LPS to express their "liking" of a language. Zane started his explanation of his description (Figure 2) with "depending on how low the language is, that says how much I like the language." Further, he reported that putting a language "high" on his body indicated it as his favourite: "Deutsch [German]." He further linked his attachment to German with his perception that "it's the easiest [to learn]." In other words, his attachment to German might have been due to his expertise in German through schooling. For Reja, expertise and attachment also go together. "I like both of them and I can speak both of them." For both of these children, expertise and attachment are connected.

\section{Inheritance}

Inheritance refers to having a familial connection to a language. This connection can take the form of actual linguistic expertise in families that still speak the language, but can also be found in the linguistic identities of children who have had stories or aspects of culture passed down to them that link their family to the language.

Some of the children in the study came from families that spoke languages other than English at home; of those, some also referenced family members who share that language. As mentioned earlier, after pointing to his LPS, Sean said, "I think in German," and then added, "My mom speaks to me [in German]." When asked "Why did you put German here on your picture?" Stryker said he spoke German mostly when he visited another town

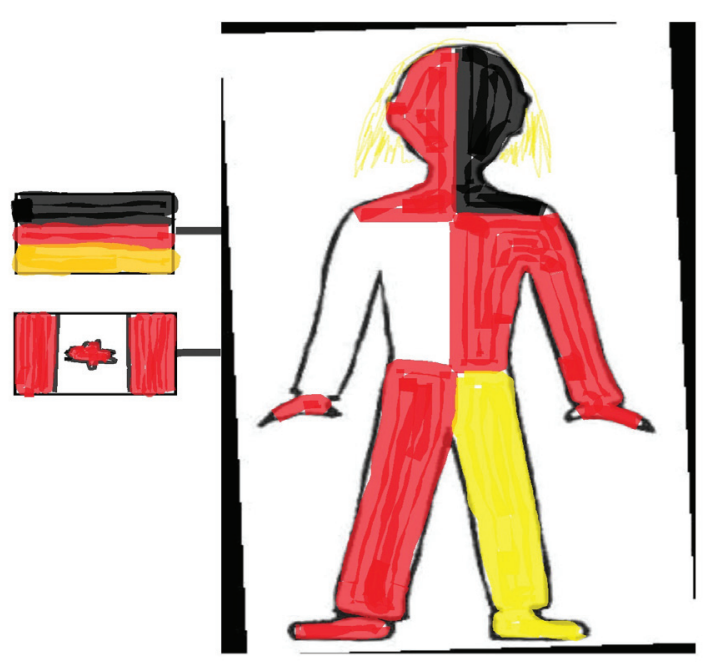

Figure 4: Reja's Language Portrait Silhouette 
and that the family members that live there ("one of [his] grandmas, one of [his] grandpas, one of [his] cousins, one of [his] aunts and another aunt") all spoke German. Yousef's family language, Arabic, held a less prominent, almost invisible place in the classroom (Gkaintartzi, Kiliari, \& Tsokalidou, 2015). In explaining the inclusion of Arabic on his LPS, he emphasized that his whole family "is almost Arabic" and he spoke Arabic "with my grandpa." Most of the children that spoke languages other than English at home-including Sean, Stryker, Reja, and Yousef, featured in this article-mentioned in their videotaped narrative the languages they have in common with family members, thereby referencing inheritance as a part of their linguistic identity.

The children in this study expressed linguistic identity in terms of expertise, affiliation, and inheritance. To them, expertise meant being able to speak the language. The children's identification and attachment to their languages was expressed through flags and "liking" the languages, both aspects of affiliation. As well, many children said they placed their home languages on the body in their LPS because they had inherited them from their families.

Asking the children to describe their LPS gave them the opportunity to speak about all of their languages. The LPS was useful in getting the children to talk about all aspects of their linguistic identity, and bring into the classroom languages that may not otherwise have been discussed, thereby validating these languages within the school context (Cummins \& Early, 2011). The use of the LPS in this research demonstrated one way in which the tool can be used to initiate and facilitate a discussion of linguistic identity in the classroom.

\section{The Language Portrait Silhouette in the Classroom}

For teachers, the LPS can provide a catalyst for dialogue and understanding regarding linguistic identity, just as it did for this research. The LPS is a simple activity that takes very little class time, but provides valuable material for discussion. Teachers and children can discuss what languages are used by classmates, what it means to be multilingual, and in which situations we use our different languages. They can draw upon the affordances of multimodality, including colours and symbols (Kress \& van Leeuwen, 2006). There are a number of ways in which the LPS can be used in the school and in the classroom to initiate these conversations with students.

Students benefit from seeing their teachers and other adults in the school as language learners, but adults first need to understand for themselves what constitutes their own linguistic identity (Morgan, 2004; Pavlenko, 2003). The LPS is a straightforward task that could be completed and discussed by all teachers and staff at the beginning of the school year as an icebreaker, perhaps at the first gathering. This icebreaker would allow teachers and staff to address their own perceptions of what it means to be bilingual. The teachers and staff could ask themselves what expertise, affiliation, and inheritance 
they have and how that impacts their perception of their students' emerging multilingualism (Gkaintartzi \& Tsokalidou, 2011). The resulting understanding could help them when encouraging students to see language learning as a lifelong language endeavour.

Taking it a step further, teachers and staff could turn their LPSs into posters. With these posters around the school, students would have the chance to see and read about the varied linguistic identities of the adults in their learning environment. These posters would serve to passively introduce the activity before it is used in class or, conversely, could be reserved until after the students have completed theirs, to encourage discussions around linguistic identity without influencing the students' LPS creations.

Completing the LPS could also be a class activity. Students could present their silhouettes to their classmates, providing examples of what they can say in each of their languages. Alternatively, for older students the task can involve writing about their languages in whatever languages they feel comfortable using (Taylor, Bernhard, Garg, \& Cummins, 2008). This expands the task into a written activity that draws upon the linguistic repertoire of the students (Cummins, 2006). Teachers could be encouraged to conduct this activity in classes with monolingual students as well, normalizing multilingualism while validating the languages the students already speak, even if there is only one. This activity would encourage the students in their efforts to learn additional languages formally (in second language classes in school) and informally (from friends or family) (Eaton, 2010). If this task were repeated each year, the students would have a portfolio of their developing expressions of linguistic identity, adding languages as they encounter them in their lives.

These are a few ways in which teachers can use the LPS to facilitate discussions about the nature of multilingualism and linguistic identity. Its simplicity allows for creativity in multimodal expression through text, colour, and symbols. In addition, it holds the potential for expansion across time, as students compare the drawings of older and younger children or their own creations over time. All of these activities serve to validate the linguistic identities of the children within the school.

\section{Conclusion}

Imagine a school where the hallways are decorated with posters celebrating the rich linguistic repertoire of the teachers, staff, and students presented through visuals and symbols (Kress, 1997, 2010; Kress \& van Leeuwen, 2006). In this context, multilingualism would be valued and languages that are not taught would still have a place (Cummins \& Early, 2011). Within the classrooms, students might feel encouraged to draw upon their languages to facilitate their understanding of school work. They may feel proud of their skills and appreciate the skills of others. Linguistic identity is defined to in- 
clude expertise, affiliation, and inheritance, and one or more of these three aspects emerges in the analysis of an individual's expression of linguistic identity (Block, 2014; Leung et al., 1997). When students are discouraged by or struggling with learning, teachers can point to others who have persevered in language learning and emphasize an attitude of lifelong language learning. The validation and understanding of linguistic identity would prove beneficial for young children's emotional, social, and educational development by acknowledging or finding a place for their home languages in the school.

\section{The Author}

Roswita Dressler, PhD, works as an instructor in the Werklund School of Education at the University of Calgary. Her research in bilingual education and childhood bilingualism includes a focus on identity. She is a former second language teacher (German, French, ESL) and coordinates a volunteer community ESL program for adults.

\section{Acknowledgements}

This research was part of a larger study funded by a Joseph Armand Bombardier Scholarship from the Social Sciences and Humanities Research Council of Canada. I would like to acknowledge the support of Dr. Mary Grantham O'Brien for the larger project and Dr. Sarah Eaton, Dr. Katherine Mueller, and Dr. Kim Lenters for their assistance with this specific article.

\section{Note}

1 Used with written permission from Hans-Jürgen Krumm.

\section{References}

Arnesen, A.-L., Allan, J., Simonsen, E., \& Council of Europe. (2010). Policies and practices for teaching sociocultural diversity: A framework of teacher competences for engaging with diversity. Strasbourg, France: Council of Europe.

Block, D. (2014). Second language identities. London, UK: Bloomsbury.

Busch, B. (2010). School language profiles: Valorizing linguistic resources in heteroglossic situations in South Africa. Language and Education, 24(4), 283-294. doi:10.1080/09500781003678712

Busch, B. (2012). The linguistic repertoire revisited. Applied Linguistics, 33(5), 503-523. doi:10.1093/ applin/ams056

Cummins, J. (2006). Identity texts: The imaginative construction of self through multiliteracies pedagogy. In O. García, T. Skutnabb-Kangas, \& M. E. Torres-Guzmán (Eds.), Imagining multilingual schools: Languages in education and glocalization (pp. 51-69). Clevedon, UK: Multilingual Matters.

Cummins, J., \& Early, M. (2011). Identity texts: The collaborative creation of power in multilingual schools. Stoke on Trent, UK: Trentham Books.

Dressler, R. (2010). "There is no space for being German": Portraits of willing and reluctant Heritage Language Learners of German. Heritage Language Journal, 7(2), 1-15. Retrieved from www.heritagelanguages.org

Eaton, S. E. (2010). Formal, non-formal and informal learning: The case of literacy, essential skills and language learning in Canada. Calgary, AB: Eaton International Consulting.

Eccles, J. S. (1999). The development of children ages 6 to 14. The Future of Children, 9(2), 30-44.

Garcia, O. (2009). Education, multilingualism and translanguaging in the 21st century. In T. Skutnabb-Kangas, R. Phillipson, A. K. Mohanty, \& M. Panda (Eds.), Social justice through multilingual education (pp. 140-158). Bristol, UK: Multilingual Matters. 
Gkaintartzi, A., Kiliari, A., \& Tsokalidou, R. (2015). 'Invisible' bilingualism - 'invisible' language ideologies: Greek teachers' attitudes towards immigrant pupils' heritage languages. International Journal of Bilingual Education and Bilingualism, 18(1), 60-72. doi:10.1080/136700 50.2013 .877418

Gkaintartzi, A., \& Tsokalidou, R. (2011). "She is a very good child but she doesn't speak": The invisibility of children's bilingualism and teacher ideology. Journal of Pragmatics, 43(2), 588-601. doi:10.1016/j.pragma.2010.09.014

Gogolin, I., \& Neumann, U. (1991). DIL - LANGUAGE - LINGUA - Sprachliches Handeln in der Grundschule [DIL - LANGUAGE - LINGUA: Language negotiation in elementary school]. Die Grundschulzeitschrift, 43, 6-13.

Kress, G. (1997). Before writing: Rethinking the paths to literacy. London, UK: Routledge.

Kress, G. (2010). Multimodality: A social semiotic approach to contemporary communication. London, UK: Routledge.

Kress, G., \& van Leeuwen, T. (2006). Reading images: The grammar of visual design. London, UK: Routledge.

Krumm, H.-J., \& Jenkins, E.-M. (2001). Kinder und ihre Sprachen - lebendige Mehrsprachigkeit. Sprachenporträts - gesammelt und kommentiert von Hans-Jürgen Krumm [Children and their languages - vibrant multilingualism: Language portraits collected and commented on by Hans-Jürgen Krumm]. Vienna, Austria: Eviva Verlag.

Leung, C., Harris, R., \& Rampton, B. (1997). The idealised native speaker, reified ethnicities, and classroom realities. TESOL Quarterly, 31(3), 543-560. doi:10.2307/3587837

Lundell, L. (2010). "What is the color of English?" Representation of English in the language portraits of Sámi children (Master's thesis). University of Jyväskylä, Finland. Retrieved from https://jyx.jyu.fi/dspace/bitstream/handle/123456789/25107/URN:NBN:fi:jyu-201009212665. pdf? sequence $=1$

Martin, B. (2012). Coloured language: Identity perception of children in bilingual programmes. Language Awareness, 21(1-2), 33-56. doi:10.1080/09658416.2011.639888

Moore, D. (2010). Multilingual literacies and third script acquisition: Young Chinese children in French immersion in Vancouver, Canada. International Journal of Multilingualism, 7(4), 322-342. doi:10.1080/14790718.2010.502231

Morgan, B. (2004). Teacher identity as pedagogy: Towards a field-internal conceptualisation in bilingual and second language education. International Journal of Bilingual Education and Bilingualism, 7(2-3), 172-188. doi:10.1080/13670050408667807

Pavlenko, A. (2003). "I never knew I was a bilingual”: Reimagining teacher identities in TESOL. Journal of Language, Identity, \& Education, 2(4), 251-268. doi:10.1207/S15327701JLIE0204

Portnaia, N. (2014). Sprachlernsituationen der Kinder mit migrationsbedingter Zwei-/Mehrsprachigkeit beim Fremdsprachenlernen in der Grundschule: Eine qualitative Studie unter besonderer Beruecksichtigung der Herkunftssprache Russisch [Language learning situations of bi-/multilingual immigrant children in elementary school foreign language learning contexts: A qualitative study with a particular focus on children with Russian as a heritage language]. Berlin, Germany: Logos Verlag.

Taylor, L. K., Bernhard, J. K., Garg, S., \& Cummins, J. (2008). Affirming plural belonging: Building on students' family-based cultural and linguistic capital through multiliteracies pedagogy. Journal of Early Childhood Literacy, 8(3), 269-294. doi:10.1177/1468798408096481 